\author{
Correspondence \\ Wen-Jun Li \\ wjli@ynu.edu.cn \\ Chang-Jin Kim \\ changjin@kribb.re.kr
}

\section{Aidingimonas halophila gen. nov., sp. nov., a moderately halophilic bacterium isolated from a salt lake}

\author{
Yun Wang, ${ }^{1}$ † Shu-Kun Tang, ${ }^{2}{ }^{\dagger} \mathrm{Kai}$ Lou, ${ }^{1}$ Jae-Chan Lee, ${ }^{3}$ Che Ok Jeon, ${ }^{4}$ \\ $\mathrm{Li}-\mathrm{H}$ ua $\mathrm{Xu},{ }^{2}$ Chang-Jin $\mathrm{Kim}^{3}$ and Wen-Jun $\mathrm{Li}^{2}$ \\ ${ }^{1}$ Xinjiang Institute of Microbiology, Xinjiang Academy of Agricultural Science, Urumqi, Xinjiang \\ 830091, PR China
${ }^{2}$ The Key Laboratory for Microbial Resources of Ministry of Education and Laboratory for Conservation and Utilization of Bio-resources, Yunnan Institute of Microbiology, Yunnan University, Kunming 650091, PR China
${ }^{3}$ Korea Research Institute of Bioscience and Biotechnology, 52 Oeundong, Yusong, Daejeon 305- 333, Republic of Korea \\ ${ }^{4}$ Department of Life Science, Chung-Ang University, Seoul 156-756, Republic of Korea
}

Two Gram-negative, facultatively anaerobic, catalase-positive, oxidase-negative, non-motile, rodshaped and moderately halophilic bacterial strains, designated $\mathrm{YIM} 90637^{\top}$ and $\mathrm{BH} 017$, were isolated from a salt lake in Xinjiang province, north-west China, and subjected to a polyphasic taxonomic study. Phylogenetic analysis based on 16S rRNA gene sequences revealed that the two novel isolates were affiliated with the family Halomonadaceae; the two strains shared $100 \%$ sequence similarity, but showed similarities of $94.7 \%$ with the type strain of Modicisalibacter tunisiensis, 93.2-94.7\% with members of the genus Chromohalobacter, 93.2-95.0\% with members of the genus Halomonas and less than $92.0 \%$ with other members of the family Halomonadaceae. However, DNA-DNA relatedness data and phenotypic properties demonstrated that strains $\mathrm{YIM} 90637^{\top}$ and $\mathrm{BH} 017$ were representatives of the same species. The major fatty acids were $\mathrm{C}_{19: 0}$ cyclo $\omega 8 \mathrm{c}$ and $\mathrm{C}_{16: 0}$. The relative amount of $\mathrm{C}_{19: 0}$ cyclo $\omega 8 \mathrm{c}$ was notably higher than that found in most species of the family Halomonadaceae for which fatty acid composition has been determined. The genomic DNA G + C content was 57.2-57.5 mol\% and the only respiratory quinone was ubiquinone 9 . Based on evidence from the polyphasic taxonomic study, it was concluded that the two strains should be classified as representatives of a novel species in a new genus, for which name Aidingimonas halophila gen. nov., sp. nov. is

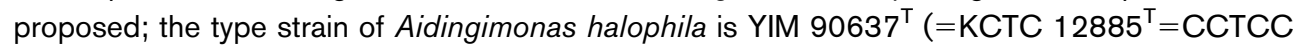
AB $207002^{\top}$ ).
The family Halomonadaceae was first proposed on the basis of results obtained with the $16 \mathrm{~S}$ rRNA cataloguing technique (Franzmann et al., 1988). The family Halomonadaceae belongs to the class Gammaproteobacteria and, at the time of writing, included four genera of halophilic bacteria (Halomonas, Chromohalobacter, Modicisalibacter and Cobetia) and three genera of non-halophilic bacteria

†These authors contributed equally to this work.

The GenBank/EMBL/DDBJ accession numbers for the 16S rRNA gene sequences of strains YIM $90637^{\top}$ and $\mathrm{BH} 017$ are FJ418176 and EU191906, respectively.

The polar lipid composition of strain YIM $90637^{\top}$ and the cellular fatty acid profiles of strains YIM $90637^{\top}$ and $\mathrm{BH} 017$ are available as supplementary material with the online version of this paper.
(Zymobacter, Halotalea and Carnimonas) (Okamoto et al., 1993; Dobson \& Franzmann, 1996; Mata et al., 2002; Ventosa et al., 1998; Ben Ali Gam et al., 2007; Ntougias et al., 2007). Halomonas is the largest genus in the family Halomonadaceae and currently comprises more than 50 species. More than half of the taxa in the family Halomonadaceae have been reclassified because of their heterogeneous features (Franzmann et al., 1988; Mellado et al., 1995; Dobson \& Franzmann, 1996; Arahal et al., $2002 a, b)$ and the description of the family has been emended three times (Dobson \& Franzmann, 1996; Ntougias et al., 2007; Ben Ali Gam et al., 2007). Nevertheless, the taxonomic status of some taxa, e.g. Cobetia marina, Halomonas marisflavi, Halomonas indalinina, Halomonas avicenniae and Halomonas salaria, is still 
in doubt (Kim et al., 2007). In this paper, two novel bacterial strains, designated YIM $90637^{\mathrm{T}}$ and $\mathrm{BH} 017$, are described and their morphological, physiological, chemotaxonomic and phylogenetic characteristics are identified. Due to their unique taxonomic position, it is concluded that the two isolates represent a novel species in a new bacterial genus in the family Halomonadaceae.

The two strains were isolated from sediment samples taken from Aiding Lake, which is situated in the southern part of the Turpan Basin in Xinjiang Uygur Autonomous Region, north-west China, about $40 \mathrm{~km}$ south of the city of Turpan. Aiding Lake is a salt lake with an area of $124 \mathrm{~km}^{2}$ and, at $155 \mathrm{~m}$ below sea level, is the lowest place in China and the second lowest place in the world, next only to the Dead Sea. The mineral content of the water is as high as $200 \mathrm{~g} \mathrm{l}^{-1}$ due to many years of strong evaporation. The major ions are $\left(\mathrm{mg} \mathrm{l}^{-1}\right) \mathrm{Na}^{+}(127764.8), \mathrm{K}^{+}$(529.1), $\mathrm{Ca}^{2+}$ (151.9), $\mathrm{Mg}^{2+}$ (597.8), $\mathrm{Cl}^{-}$(177529.5), $\mathrm{SO}_{4}^{2-}$ (29635.2) and $\mathrm{HCO}_{3}^{-}$(200.1). Strain YIM $90637^{\mathrm{T}}$ was isolated by the dilution plating method on cellulose-caseinmultisalts medium described by Tang et al. (2008), whereas strain $\mathrm{BH} 017$ was isolated on marine agar 2216 (MA; Difco) with the addition of $8 \%(\mathrm{w} / \mathrm{v}) \mathrm{NaCl}$ (final $\mathrm{NaCl}$ concentration $9.94 \%, w / v)$. The two strains were maintained on modified ISP 2 agar (Shirling \& Gottlieb, 1966) slants containing $10 \% \mathrm{NaCl}(\mathrm{w} / \mathrm{v})$ at $4{ }^{\circ} \mathrm{C}$ and as $20 \%$ $(w / v)$ glycerol suspensions at $-20{ }^{\circ} \mathrm{C}$. The modified ISP 2 medium contained (per 1 distilled water) $4 \mathrm{~g}$ yeast extract, $10 \mathrm{~g}$ malt extract, $4 \mathrm{~g}$ glucose, $100 \mathrm{~g} \mathrm{NaCl}$ and $15 \mathrm{~g}$ agar. The medium was adjusted to $\mathrm{pH}$ 7.0. Biomass for chemical and molecular studies was obtained by cultivation in shaken flasks (about 150 r.p.m.) using ISP 2 medium supplemented with $10 \% \mathrm{NaCl}$ at $37{ }^{\circ} \mathrm{C}$ for about a week.

Gram staining was carried out by the standard Gram reaction and was confirmed by using the $\mathrm{KOH}$ lysis test method (Cerny, 1978). Morphology was examined by transmission electron microscopy with a model H-800 transmission electron microscope (Hitachi) using cells from exponentially growing cultures. Motility was observed both on modified ISP 2 medium with $0.3 \%$ agar under high-moisture conditions and in a hanging-drop preparation under an oil-immersion objective. Accumulation of poly- $\beta$-hydroxybutyrate was determined by the Sudan black staining method under a light microscope (Smibert \& Krieg, 1994). Colony morphology was observed on modified ISP 2 medium containing $10 \%$ $\mathrm{NaCl}$ after incubation at $37{ }^{\circ} \mathrm{C}$ for 7 days. Growth at various temperatures $(0,4,10,15,20,28,30,37,40,45,50$ and $55{ }^{\circ} \mathrm{C}$ ) was tested on modified ISP 2 medium containing $10 \% \mathrm{NaCl}$. The $\mathrm{pH}$ range for growth was investigated between $\mathrm{pH} 4.0$ and 10.0 (at intervals of 1.0 $\mathrm{pH}$ unit) using the buffer system described by $\mathrm{Xu}$ et al. (2005). Liquid cultures were cultivated in tubes at $37{ }^{\circ} \mathrm{C}$ for $2-3$ weeks using modified ISP 2 containing $10 \% \mathrm{NaCl}$ as the basal medium. Growth at various salt concentrations $[0-30 \% \mathrm{NaCl}(\mathrm{w} / \mathrm{v})$ at intervals of $1 \%]$ was tested by using ISP 2 without any added salts as the basal medium.
Catalase activity was determined by production of bubbles after the addition of a drop of $3 \% \mathrm{H}_{2} \mathrm{O}_{2}$. Oxidase activity was observed by oxidation of tetramethyl- $p$-phenylenediamine. Reduction of nitrate, the methyl red and VogesProskauer tests and hydrolysis of aesculin, gelatin, casein, starch and Tweens 20,40,60 and 80 were determined as described by Cowan \& Steel (1965). Metabolic properties and enzyme activities were determined by means of the API 20NE, API 20E, API 50CHB and API ZYM systems (bioMérieux) according to the manufacturer's instructions. Utilization of organic substrates was tested using Biolog GN2 microplates. Strains were prepared using pre-warmed sterile saline medium $(10 \% \mathrm{NaCl})$, within the density range specified by the manufacturer. Antibiotic susceptibility was determined on agar using the disc diffusion method (Reva et al., 1995). Anaerobic growth experiments were performed in ISP 2 medium supplemented with $0.15 \mathrm{mM}$ nitrate and $0.035 \mathrm{mM}$ nitrite using the GasPak Anaerobic system (BBL) according to the manufacturer's instructions. Phenotypic, chemotaxonomic and phylogenetic features of the two strains were compared with those of members of related genera of the family Halomonadaceae; data are shown in Table 1.

For fatty acid analysis, strains YIM $90637^{\mathrm{T}}$ and $\mathrm{BH} 017$ were cultured on tryptic soy agar (Difco) containing $10 \%$ $\mathrm{NaCl}$ at $37{ }^{\circ} \mathrm{C}$ for $48 \mathrm{~h}$ and GC was performed as described by Sasser (1990) using the Microbial Identification system (MIDI). Isoprenoid quinones were extracted and purified as described by Komagata \& Suzuki (1987). The purified ubiquinone was dissolved in acetone and separated by reversed-phase HPLC. Polar lipids were extracted, examined by two-dimensional TLC and identified using published procedures (Minnikin et al., 1984). Levels of DNA-DNA relatedness were determined according to the optical renaturation method (De Ley et al., 1970; Huß et al., 1983; Jahnke, 1992), DNA-DNA hybridization was performed in triplicate.

Extraction of genomic DNA and PCR amplification of the 16S rRNA gene were done as described by Li et al. (2007). The obtained sequences were compared with reference $16 \mathrm{~S}$ rRNA gene sequences retrieved from GenBank and EMBL by BLAST searching and similarity searches were performed using the EzTaxon server (http://147.47.212.35:8080; Chun et al., 2007). Multiple alignments and calculations of sequence evolutionary distances were carried out using CLUSTAL_X (Thompson et al., 1997) software. Gaps at the 5' and $3^{\prime}$ ends of the alignment were omitted from further analysis. Phylogenetic analyses were performed using three tree-making algorithms, the neighbour-joining (Saitou \& Nei, 1987), maximum-likelihood (Felsenstein, 1981) and maximum-parsimony (Fitch, 1971) methods. A phylogenetic tree was constructed using the neighbour-joining method using MEGA version 4.0 (Tamura et al., 2007). The topology of the phylogenetic tree was evaluated by the bootstrap resampling method with 1000 replicates (Felsenstein, 1985). Genomic DNA for determination of the $\mathrm{G}+\mathrm{C}$ contents of strains YIM $90637^{\mathrm{T}}$ and BH 017 was 
Table 1. Selected characteristics that differentiate members of the genus Aidingimonas gen. nov. from those of related genera in the family Halomonadaceae

Genera: 1, Aidingimonas gen. nov. (strains YIM $90637^{\mathrm{T}}$ and BH 017; data from this study); 2, Halomonas (Vreeland, 2005); 3, Modicisalibacter (Ben Ali Gam et al., 2007); 4, Chromohalobacter (Ventosa, 2005; Sánchez-Porro et al., 2007; Aguilera et al., 2007); 5, Cobetia (Arahal et al., 2002a); 6, Zymobacter (Okamoto et al., 2005); 7, Halotalea (Ntougias et al., 2007); 8, Carnimonas (Garriga et al., 2005). +, Positive; -, negative; v, variable; ND, no data available.

\begin{tabular}{|c|c|c|c|c|c|c|c|c|}
\hline Characteristic & 1 & 2 & 3 & 4 & 5 & 6 & 7 & 8 \\
\hline Cell length $(\mu \mathrm{m})$ & $0.7-1.5$ & $0.6-1.9$ & $0.6-4.0$ & $0.6-4.2$ & $1.6-4.0$ & $0.7-2.4$ & ND & $0.5-1.7$ \\
\hline Cell morphology & Straight rods & $\begin{array}{l}\text { Straight or } \\
\text { curved rods } \\
\text { or coccoid }\end{array}$ & Straight rods & $\begin{array}{l}\text { Straight or } \\
\text { curved rods }\end{array}$ & $\begin{array}{l}\text { Straight } \\
\text { rods }\end{array}$ & $\begin{array}{c}\text { Rods with } \\
\text { rounded } \\
\text { ends }\end{array}$ & Rods & $\begin{array}{l}\text { Straight or } \\
\text { curved rods }\end{array}$ \\
\hline Colour & $\begin{array}{l}\text { Colourless to } \\
\text { yellow brown }\end{array}$ & $\begin{array}{l}\text { White or } \\
\text { yellow }\end{array}$ & Cream & $\begin{array}{l}\text { White, yellow } \\
\text { or brown }\end{array}$ & Cream & Milky white & Pale yellow & White \\
\hline Motility & - & $\mathrm{V}$ & + & + & - & + & + & - \\
\hline \multicolumn{9}{|l|}{ Oxygen relationship } \\
\hline Aerobic & + & + & + & + & + & + & + & + \\
\hline Facultatively anaerobic & + & $\mathrm{v}$ & - & $\mathrm{v}$ & - & + & - & - \\
\hline Oxidase test & - & + & - & $\mathrm{v}$ & - & - & + & + \\
\hline \multicolumn{9}{|l|}{ Ranges for growth } \\
\hline $\mathrm{NaCl}(\%, \mathrm{w} / \mathrm{v})$ & $1-25$ & $0-32.5$ & $1-25$ & $0-30$ & $0.5-20$ & ND & $0-15$ & $0-8$ \\
\hline Temperature $\left({ }^{\circ} \mathrm{C}\right)$ & $10-45$ & $4-45$ & $4-45$ & $0-45$ & $10-42$ & $15-37$ & $5-45$ & ND \\
\hline $\mathrm{pH}$ & $5-9$ & $4.5-10$ & $5-10$ & $5-10$ & $5-10$ & $4.7-8.1$ & $5-11$ & ND \\
\hline Nitrate reduction & + & + & + & + & - & - & - & - \\
\hline Gelatin liquefaction & - & $\mathrm{v}$ & - & - & ND & - & - & - \\
\hline \multicolumn{9}{|l|}{ Enzyme activities } \\
\hline Urease & + & $\mathrm{v}$ & - & - & + & $\mathrm{ND}$ & - & - \\
\hline Arginine dihydrolase & + & - & ND & ND & ND & - & - & - \\
\hline Ornithine decarboxylase & - & + & $\mathrm{ND}$ & $\mathrm{v}$ & ND & - & - & $\mathrm{ND}$ \\
\hline Lysine decarboxylase & - & + & ND & $\mathrm{V}$ & ND & - & - & ND \\
\hline \multicolumn{9}{|l|}{ Hydrolysis of: } \\
\hline Starch & - & - & - & - & - & ND & - & + \\
\hline Aesculin & - & $\mathrm{v}$ & - & - & - & $\mathrm{ND}$ & ND & + \\
\hline \multicolumn{9}{|l|}{$\begin{array}{l}\text { Utilization as sole carbon } \\
\text { source of: }\end{array}$} \\
\hline L-Arabinose & + & $\mathrm{v}$ & ND & + & - & - & ND & - \\
\hline Citrate & + & + & - & + & - & - & + & + \\
\hline Maltose & + & + & - & $\mathrm{ND}$ & - & + & + & + \\
\hline D-Ribose & + & $\mathrm{ND}$ & - & ND & ND & ND & ND & ND \\
\hline Xylitol & + & $\mathrm{ND}$ & - & ND & ND & ND & ND & ND \\
\hline D-Mannose & + & + & - & ND & - & $\mathrm{V}$ & + & + \\
\hline L-Lysine & - & + & $\mathrm{ND}$ & $\mathrm{ND}$ & $\mathrm{ND}$ & $\mathrm{ND}$ & - & $\mathrm{ND}$ \\
\hline L-Phenylalanine & - & + & $\mathrm{ND}$ & ND & ND & ND & $\mathrm{ND}$ & ND \\
\hline L-Leucine & - & + & $\mathrm{ND}$ & $\mathrm{ND}$ & $\mathrm{ND}$ & $\mathrm{ND}$ & $\mathrm{ND}$ & $\mathrm{ND}$ \\
\hline Major respiratory quinone & Q-9 & Q-9 & Q-9 & ND & $\mathrm{ND}$ & $\mathrm{ND}$ & Q-9 & Q-9 \\
\hline Major fatty acids $(>10 \%)$ & $\begin{array}{l}\mathrm{C}_{19: 0} \text { cyclo } \\
\omega 8 c, \mathrm{C}_{16: 0}\end{array}$ & $\begin{array}{c}\mathrm{C}_{16: 1} \omega 7 c \\
\mathrm{C}_{16: 0}, \mathrm{C}_{17: 0} \\
\text { cyclo, } \mathrm{C}_{18: 1}, \\
\mathrm{C}_{19: 0} \text { cyclo } \\
11-12\end{array}$ & $\begin{array}{c}\mathrm{C}_{16: 0}, \\
\mathrm{C}_{16: 1} \omega 7 c \\
\mathrm{C}_{18: 1} \omega 7 c \\
\mathrm{C}_{19: 0} \text { cyclo } \\
\omega 8 c\end{array}$ & $\begin{array}{c}\mathrm{C}_{16: 0}, \\
\mathrm{C}_{18: 1} \omega 7 c, \\
\mathrm{C}_{19: 0} \text { cyclo } \\
\omega 8 c\end{array}$ & $\begin{array}{c}\mathrm{C}_{16: 0}, \\
\mathrm{C}_{17: 0}, \\
\mathrm{C}_{16: 1} \omega 7 c \\
\mathrm{C}_{18: 1} \omega 7 c\end{array}$ & $\begin{array}{c}\mathrm{C}_{16: 0} \\
\mathrm{C}_{18: 1} \omega 9 c \\
\mathrm{C}_{19: 0} \text { cyclo }\end{array}$ & $\begin{array}{l}\mathrm{C}_{18: 1} \omega 7 c, \\
\mathrm{C}_{16: 0}, \mathrm{C}_{19: 0} \\
\text { cyclo } \omega 8 c, \\
\mathrm{C}_{12: 0} 3-\mathrm{OH}\end{array}$ & $\begin{array}{c}\mathrm{C}_{16: 0}, \mathrm{C}_{16: 1} \\
\mathrm{C}_{18: 1}, \mathrm{C}_{19: 0} \\
\text { cyclo }\end{array}$ \\
\hline Polar lipids ${ }^{\star}$ & $\begin{array}{c}\text { DPG, PE, PI, } \\
\text { PIM, 2PL, } \\
\text { 2PGL, GL }\end{array}$ & $\begin{array}{c}\text { DPG, PG, } \\
\text { PE, 1PL }\end{array}$ & $\mathrm{ND}$ & $\mathrm{ND}$ & ND & ND & $\mathrm{ND}$ & $\begin{array}{c}\mathrm{DPG}, \mathrm{PG}, \mathrm{PE}, \\
\text { 3PL }\end{array}$ \\
\hline $\begin{array}{l}\text { DNA G }+ \text { C content } \\
(\mathrm{mol} \%)\end{array}$ & $57-58$ & $52-68$ & 53.7 & $56-66$ & $62-64$ & $55-56$ & 64.4 & 56 \\
\hline
\end{tabular}

${ }^{*}$ DPG, Diphosphatidylglycerol; GL, unknown glycolipid; PE, phosphatidylethanolamine; PG, phosphatidylglycerol; PGL, unknown phosphoglycolipid; PI, phosphatidylinositol; PIM, phosphatidylinositol mannoside; PL, unknown phospholipid. 
prepared according to the method of Marmur (1961); DNA G $+\mathrm{C}$ contents were determined by reversed-phase HPLC (Mesbah et al., 1989).

Morphological, cultural, physiological and biochemical characteristics of strains YIM $90637^{\mathrm{T}}$ and BH 017 are given in the genus and species descriptions and shown in Table 1. Comparative 16S rRNA gene sequence analyses revealed that strains YIM $90637^{\mathrm{T}}$ and $\mathrm{BH} 017$ shared $100 \%$ sequence similarity and were most closely related to members of the family Halomonadaceae. Strains YIM $90637^{\mathrm{T}}$ and BH 017 exhibited a DNA-DNA relatedness value of $76.5 \%$, which is higher than the $70 \%$ cut-off point recommended for assignment of strains to the same genomic species, indicating that the two strains represent one unique species (Wayne et al., 1987). In view of their phenotypic, phylogenetic and genetic similarities, strains YIM $90637^{\mathrm{T}}$ and $\mathrm{BH} 017$ are representatives of the same species.

In addition, as shown in Table 1, several phenotypic and physiological characteristics can be used to differentiate strains YIM $90637^{\mathrm{T}}$ and BH 017 from related genera in the family Halomonadaceae. Strains YIM $90637^{\mathrm{T}}$ and BH 017 can be distinguished clearly from their closest phylogenetic relative, members of the genus Modicisalibacter, by their lack of motility, citrate utilization, urease activity, and utilization of citrate, lactose, maltose, D-ribose, xylitol and D-mannose. Strains YIM $90637^{\mathrm{T}}$ and BH 017 differ from the members of the genus Chromohalobacter in terms of motility and urease activity. The oxidase reaction distinguished strains YIM $90637^{\mathrm{T}}$ and $\mathrm{BH} 017$ clearly from members of the genus Halomonas. Strains YIM $90637^{\mathrm{T}}$ and BH 017 could also be distinguished from Cobetia strains by their ability to reduce nitrate and utilize citrate, lactose, maltose and mannose and their inability to hydrolyse casein. In summary, strains YIM $90637^{\mathrm{T}}$ and $\mathrm{BH} 017$ showed distinctive phenotypic and physiological features when compared with their closest relatives, i.e. members of the genus Modicisalibacter and other genera in the family Halomonadaceae (Table 1).

Strains YIM $90637^{\mathrm{T}}$ and BH 017 had cellular fatty acid profiles that contained large amounts of straight-chain, unsaturated fatty acids. The major components $(>10 \%$ of total fatty acids) were $\mathrm{C}_{19: 0}$ cyclo $\omega 8 c$ and $\mathrm{C}_{16: 0}$ (see Supplementary Table S1 in IJSEM Online). The profiles were similar to those of the type strains of previously described species belonging to the genera Modicisalibacter, Chromohalobacter, Halomonas and Cobetia, confirming the position of these strains in the family Halomonadaceae (Yoon et al., 2002; Peçonek et al., 2006). However, the relative amount of $\mathrm{C}_{19: 0}$ cyclo $\omega 8 c$ was notably higher than that observed in most species of the family Halomonadaceae. Moreover, some species of the genera Halomonas, Carnimonas and Zymobacter do not possess $\mathrm{C}_{19: 0}$ cyclo $\omega 8 c . \mathrm{C}_{16: 1} \omega 7 c$ is the major fatty acid in members of the genera Modicisalibacter and Cobetia, but was not found in strains YIM $90637^{\mathrm{T}}$ and $\mathrm{BH}$ 017. In summary, the fatty acid profiles of strains YIM $90637^{\mathrm{T}}$ and BH 017 differed from those of other members of the family Halomonadaceae, which supports the assignment of these strains to a new genus. The polar lipids of strains YIM $90637^{\mathrm{T}}$ and BH 017 comprised diphosphatidylglycerol, phosphatidylethanolamine, phosphatidylinositol, phosphatidylinositol mannosides, two unknown phospholipids, two unknown phosphoglycolipids and one unknown glycolipid. The DNA G+C contents of strains YIM $90637^{\mathrm{T}}$ and BH 017 were 57.5 and $57.2 \mathrm{~mol} \%$, respectively, which fall within the range given for species of the family Halomonadaceae (52.0-74.6 mol\%).

Almost-complete 16S rRNA gene sequences were determined for strains YIM $90637^{\mathrm{T}}$ and BH 017 and the result of alignments showed that they had highest 16S rRNA gene sequence similarity to members of the family Halomonadaceae. In a phylogenetic tree based on the neighbour-joining algorithm, strains YIM $90637^{\mathrm{T}}$ and $\mathrm{BH}$ 017 formed a distinct phylogenetic lineage within the family Halomonadaceae and clustered with the type strain of Modicisalibacter tunisiensis (Fig. 1). 16S rRNA gene sequence similarity between strains YIM $90637^{\mathrm{T}}$ and $\mathrm{BH}$ 017 and members of genera within the family Halomonadaceae was as follows: $94.7 \%$ to Modicisalibacter tunisiensis LIT2 $^{\mathrm{T}}$, $93.2-94.7 \%$ to members of the genus Chromohalobacter, 93.2-95.0\% to members of the genus Halomonas, $91.3 \%$ to Cobetia marina DSM $4741^{\mathrm{T}}, 89.8 \%$ to Zymobacter palmae $\mathrm{T} 109^{\mathrm{T}}, 90.8 \%$ to Halotalea alkalilenta AW- $7^{\mathrm{T}}$, and $90.0 \%$ to Carnimonas nigrificans $\mathrm{CTCBS}^{\mathrm{T}}$. This low level of sequence similarity indicated that strains YIM $90637^{\mathrm{T}}$ and BH 017 could be assigned to a new genus that was, phylogenetically, as distant from the genus Halomonas as from the genera Chromohalobacter and Modicisalibacter. Topologies of phylogenetic trees constructed using the maximum-likelihood and maximum-parsimony algorithms were similar to that of the tree constructed by neighbour-joining analysis (data not shown).

According to the 16S rRNA signature nucleotides that are characteristic of the family Halomonadaceae given in the emended description of Ben Ali Gam et al. (2007), strains YIM $90637^{\mathrm{T}}$ and $\mathrm{BH} 017$ possessed all 18 characteristic bases at positions $484(\mathrm{~A}), 486(\mathrm{C}), 640(\mathrm{~A}), 660(\mathrm{~A}), 668$ (A), 669 (A), 737 (U), $738(\mathrm{U}), 745(\mathrm{U}), 776(\mathrm{U}), 1124(\mathrm{U}$ or G), 1297 (U), 1298 (C), $1423(\mathrm{~A}), 1424(\mathrm{C}), 1439(\mathrm{U})$, 1462 (A) and 1464 (C). These 16S rRNA signature nucleotides were all present in the sequence of Modicisalibacter tunisiensis $\mathrm{LIT}^{\mathrm{T}}$. However, there was at least one base position that differed from those of other genera in the family Halomonadaceae. When the sequences of positions 61-106 (including positions 76-93) were folded using the standard conditions of the RNA structure program (version 4.2), members of the genera Carnimonas, Chromohalobacter, Cobetia and Modicisalibacter formed a 6 bp stem, whereas members of the genera Zymobacter and Halotalea and strains YIM $90637^{\mathrm{T}}$ and BH 017 formed a 7 bp stem (data not shown). 


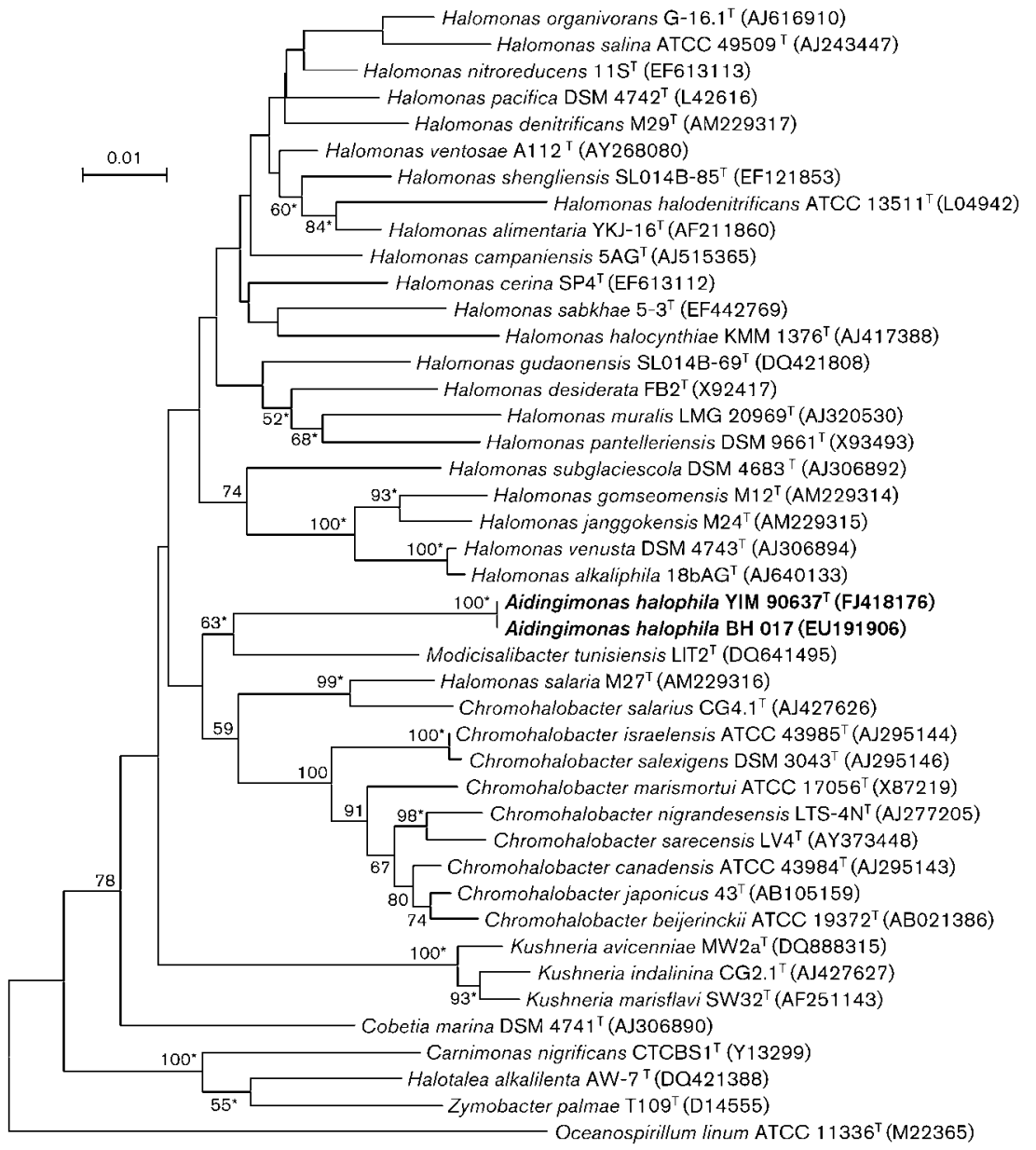

Fig. 1. Phylogenetic position of YIM $90637^{\top}$, $\mathrm{BH} 017$ and representatives of some related taxa. The topology was inferred using the neighbour-joining method (Saitou \& Nei, 1987) based on bootstrap analysis of 1000 trees; bootstrap values are shown at nodes. Asterisks indicate branches that were recovered with all three tree-making methods [maximum-likelihood (Felsenstein, 1981), maximum-parsimony (Fitch, 1971) and neighbourjoining]. The sequence of Oceanospirillum linum ATCC $11336^{\top}$ was chosen arbitrarily as an outgroup. Bar, 0.01 substitutions per site.
On the basis of chemotaxonomic, phylogenetic and phenotypic differences between the two isolates and their closest neighbours in the family Halomonadaceae, it is proposed that strains YIM $90637^{\mathrm{T}}$ and BH 017 represent a novel species in a new genus in the family Halomonadaceae for which the name Aidingimonas halophila gen. nov., sp. nov. is proposed.

\section{Description of Aidingimonas gen. nov.}

Aidingimonas (Ai.ding.i.mo'nas. N.L. n. Aiding a lake located in Xinjiang province of north-west China; L. fem. n. monas, monad a unit, a monad; N.L. fem. n. Aidingimonas a monad from Aiding Lake).

Cells are Gram-negative, facultatively anaerobic, nonendospore-forming, short rods. Non-motile without flagella. Moderately halophilic. Positive for catalase activity. Negative for oxidase activity and nitrate reduction. Ubiquinone 9 is present. Major fatty acids are $\mathrm{C}_{19: 0}$ cyclo $\omega 8 c$ and $\mathrm{C}_{16: 0}$. The DNA $\mathrm{G}+\mathrm{C}$ content is about $57-$ $58 \mathrm{~mol} \%$ (HPLC). The polar lipid pattern consists of diphosphatidylglycerol, phosphatidylethanolamine, phosphatidylinositol, phosphatidylinositol mannosides, two unknown phospholipids, two unknown phosphoglycolipids and one unknown glycolipid. The genus belongs to the family Halomonadaceae. The type species is Aidingimonas halophila.

\section{Description of Aidingimonas halophila sp. nov.}

Aidingimonas halophila (ha.lo' phi.la. Gr. n. hals, halos salt; Gr. adj. philos loving; N.L. fem. adj. halophila salt loving).

Exhibits the following properties in addition to those given for the genus. Colonies are colourless to yellow brown, flat and opaque with slightly irregular edges on modified ISP 2 medium. Cells are straight rods $(0.1-0.3 \times 0.7-1.5 \mu \mathrm{m})$. Growth occurs at $10-45{ }^{\circ} \mathrm{C}$, at $\mathrm{pH} 5.0-10.0$ and in $1-25 \%$ (w/v) $\mathrm{NaCl}$, with optimal growth at $37^{\circ} \mathrm{C}, \mathrm{pH} 7.0-8.0$ and $5-10 \% \mathrm{NaCl}$. Non-endospore-forming. Does not contain poly- $\beta$-hydroxybutyrate granules or produce exopolysaccharide. Growth occurs under anoxic conditions in the presence of nitrate ion as electron acceptor. The VogesProskauer test is variable. Indole and $\mathrm{H}_{2} \mathrm{~S}$ are not produced. Milk peptonization and coagulation and the methyl red test are negative. Gelatin, aesculin, casein, starch, and Tweens 40, 60 and 80 are not hydrolysed, but 
positive for hydrolysis of Tween 20 and urea. $o$-Nitrophenyl $\beta$-D-galactopyranosidase, phenylalanine deaminase and lysine and ornithine decarboxylase tests are negative, but positive for arginine dihydrolase. Citrate can be utilized. In the API ZYM system, positive for alkaline phosphatase, esterase (C4), esterase lipase (C8), acid phosphatase, naphthol-AS-BI-phosphohydrolase and $\alpha$-glucosidase, but negative for lipase (C14), leucine arylamidase, valine arylamidase, cystine arylamidase, trypsin, $\alpha$-chymotrypsin, $\alpha$-galactosidase, $\beta$-glucosidase, $\beta$ galactosidase, $\beta$-glucosidase, $\beta$-glucuronidase, $N$-acetyl- $\beta$ glucosaminidase, $\alpha$-mannosidase and $\alpha$-fucosidase. Acid is produced from L-arabinose, D-ribose, D-xylose, D-galactose, D-glucose, cellobiose, maltose, lactose, melibiose, gentiobiose, D-fucose and potassium 5-ketogluconate (API 50CHB). The following substrates are utilized as sole carbon or nitrogen and energy sources in the Biolog GN2 system: $\alpha$-cyclodextrin, dextrin, glycogen, Tweens 40 and $80, \mathrm{~N}$-acetyl-D-glucosamine, adonitol, L-arabinose, D-arabitol, cellobiose, erythritol, D-fructose, L-fucose, D-galactose, gentiobiose, $\alpha$-D-glucose, myo-inositol, $\alpha$-lactose, maltose, D-mannitol, D-mannose, melibiose, methyl $\beta$-Dglucoside, D-psicose, raffinose, L-rhamnose, D-sorbitol, sucrose, trehalose, turanose, xylitol, methyl pyruvate, monomethyl succinate, acetic acid, cis-aconitic acid, citric acid, formic acid, D-galactonic acid lactone, D-galacturonic acid, D-gluconic acid, D-glucosaminic acid, D-glucuronic acid, $\beta$-hydroxybutyric acid, $\alpha$-ketoglutaric acid, DL-lactic acid, malonic acid, propionic acid, D-saccharic acid, succinic acid, bromosuccinic acid, succinamic acid, glucuronamide, L-alaninamide, D- and L-alanine, L-alanyl glycine, L-asparagine, L-aspartic acid, L-glutamic acid, glycyl L-aspartic acid, glycyl L-glutamic acid, L-histidine, hydroxy-L-proline, L-ornithine, L-proline, D- and L-serine, L-threonine, $\gamma$-aminobutyric acid, urocanic acid, uridine, putrescine, 2-aminoethanol, 2,3-butanediol, glycerol, glucose 1-phosphate and glucose 6-phosphate. The following substrates in the Biolog GN2 system are negative: $N$-acetylD-galactosamine, lactulose, $\alpha$-hydroxybutyric acid, $\gamma$ hydroxybutyric acid, $p$-hydroxyphenylacetic acid, itaconic acid, $\alpha$-ketobutyric acid, $\alpha$-ketovaleric acid, quinic acid, sebacic acid, L-leucine, L-phenylalanine acid, L-pyroglutamic acid, DL-carnitine, inosine, thymidine, phenylethylamine and DL- $\alpha$-glycerol phosphate. Sensitive to the following antibiotics (per disc): amoxicillin $(10 \mu \mathrm{g})$, chloramphenicol $(30 \mu \mathrm{g})$, ciprofloxacin $(5 \mu \mathrm{g})$, erythromycin $(15 \mu \mathrm{g})$, netilmicin $(10 \mu \mathrm{g})$, norfloxacin $(10 \mu \mathrm{g})$, penicillin $(10 \mathrm{U})$, sulfamethoxazole/trimethoprim (23.75/ $1.25 \mu \mathrm{g})$, tetracycline $(30 \mu \mathrm{g})$ and vancomycin $(30 \mu \mathrm{g})$. Resistant to clindamycin $(2 \mu \mathrm{g})$, gentamicin $(10 \mu \mathrm{g})$, novobiocin $(5 \mu \mathrm{g})$, streptomycin $(10 \mu \mathrm{g})$ and tobramycin $(10 \mu \mathrm{g})$. The fatty acids $(>1 \%)$ are $\mathrm{C}_{19: 0}$ cyclo $\omega 8 c, \mathrm{C}_{16: 0}$, $\mathrm{C}_{18: 1} \omega 7 c, \mathrm{C}_{12: 0} 3-\mathrm{OH}, \mathrm{C}_{10: 0}, \mathrm{C}_{17: 0}$ cyclo and $\mathrm{C}_{12: 0}$.

The type strain is YIM $90637^{\mathrm{T}}\left(=\mathrm{KCTC} 12885^{\mathrm{T}}=\mathrm{CCTCC}\right.$ $A B 207002^{\mathrm{T}}$ ), isolated from a salt lake in Xinjiang province, north-west China. The DNA G + C content of the type strain is $57.5 \mathrm{~mol} \%$.

\section{Acknowledgements}

The authors are grateful to Dr Jean P. Euzéby for the Latin construction of the new taxon name. This research was supported by the National Basic Research Program of China (no. 2010CB833800), the National Natural Science Foundation of China (nos 30600001, 30860002, 30870005), the 973 Pre-research Program of Chain (2008CB417214), the Ministry of Science of Technology, PR China (2006DFA33550), Yunnan Provincial Natural Science Foundation (nos 2009AC017, 2009DA002), the Youth Technological Innovation Foundation of Xinjiang Academy of Agricultural Science (no. 2007Q07), the Open Project Program of the Extremophiles Lab of Xinjiang (no. XJYS0203-2005-01) and the 21C Frontier Program of Microbial Genomics and Applications from the MEST, Korea.

\section{References}

Aguilera, M., Cabrera, A., Incerti, C., Fuentes, S., Russell, N. J., Ramos-Cormenzana, A. \& Monteoliva-Sánchez, M. (2007). Chromohalobacter salarius sp. nov., a moderately halophilic bacterium isolated from a solar saltern in Cabo de Gata, Almería, southern Spain. Int J Syst Evol Microbiol 57, 1238-1242.

Arahal, D. R., Castillo, A. M., Ludwig, W., Schleifer, K. H. \& Ventosa, A. (2002a). Proposal of Cobetia marina gen. nov., comb. nov., within the family Halomonadaceae, to include the species Halomonas marina. Syst Appl Microbiol 25, 207-211.

Arahal, D. R., Ludwig, W., Schleifer, K. H. \& Ventosa, A. (2002b). Phylogeny of the family Halomonadaceae based on 23S and 16S rDNA sequence analyses. Int J Syst Evol Microbiol 52, 241-249.

Ben Ali Gam, Z., Abdelkafi, S., Casalot, L., Tholozan, J. L., Oueslati, R. \& Labat, M. (2007). Modicisalibacter tunisiensis gen. nov., sp. nov., an aerobic, moderately halophilic bacterium isolated from an oilfieldwater injection sample, and emended description of the family Halomonadaceae Franzmann et al. 1989 emend. Dobson and Franzmann 1996 emend. Ntougias et al. 2007. Int J Syst Evol Microbiol 57, 2307-2313.

Cerny, G. (1978). Studies on the aminopeptidase test for the distinction of Gram-negative from Gram-positive bacteria. Appl Microbiol Biotechnol 5, 113-122.

Chun, J., Lee, J.-H., Jung, Y., Kim, M., Kim, S., Kim, B. K. \& Lim, Y. W. (2007). EzTaxon: a web-based tool for the identification of prokaryotes based on 16S ribosomal RNA gene sequences. Int J Syst Evol Microbiol 57, 2259-2261.

Cowan, S. T. \& Steel, K. J. (1965). Manual for the Identification of Medical Bacteria. London: Cambridge University Press.

De Ley, J., Cattoir, H. \& Reynaerts, A. (1970). The quantitative measurement of DNA hybridization from renaturation rates. Eur $J$ Biochem 12, 133-142.

Dobson, S. J. \& Franzmann, P. D. (1996). Unification of the genera Deleya (Baumann et al. 1983), Halomonas (Vreeland et al. 1980), and Halovibrio (Fendrich 1988) and the species Paracoccus halodenitrificans (Robinson and Gibbons 1952) into a single genus, Halomonas, and placement of the genus Zymobacter in the family Halomonadaceae. Int J Syst Bacteriol 46, 550-558.

Felsenstein, J. (1981). Evolutionary trees from DNA sequences: a maximum likelihood approach. J Mol Evol 17, 368-376.

Felsenstein, J. (1985). Confidence limits on phylogenies: an approach using the bootstrap. Evolution 39, 783-791.

Fitch, W. M. (1971). Toward defining the course of evolution: minimum change for a specific tree topology. Syst Zool 20, 406416. 
Franzmann, P. D., Wehmeyer, U. \& Stackebrandt, E. (1988). Halomonadaceae fam. nov., a new family of the class Proteobacteria to accommodate the genera Halomonas and Deleya. Syst Appl Microbiol 11, 16-19.

Garriga, M., Ehrmann, M. A., Arnau, J., Hugas, M. \& Vogel, R. F. (2005). Genus II. Carnimonas Garriga, Ehrmann, Arnau, Hugas and Vogel 1998, 684 ${ }^{\mathrm{VP}}$. In Bergey's Manual of Systematic Bacteriology, 2nd edn, vol. 2, part B, pp. 313-315. Edited by D. J. Brenner, N. R. Krieg, J. T. Staley \& G. M. Garrity. New York: Springer.

Huß, V. A. R., Festl, H. \& Schleifer, K. H. (1983). Studies on the spectrophotometric determination of DNA hybridization from renaturation rates. Syst Appl Microbiol 4, 184-192.

Jahnke, K. D. (1992). BASIC computer program for evaluation of spectroscopic DNA renaturation data from Gilford System 2600 spectrophotometer on a PC/XT/AT type personal computer. J Microbiol Methods 15, 61-73.

Kim, K. K., Jin, L., Yang, H. C. \& Lee, S. T. (2007). Halomonas gomseomensis sp. nov., Halomonas janggokensis sp. nov., Halomonas salaria sp. nov. and Halomonas denitrificans sp. nov., moderately halophilic bacteria isolated from saline water. Int J Syst Evol Microbiol 57, 675-681.

Komagata, K. \& Suzuki, K. (1987). Lipid and cell-wall analysis in bacterial systematics. Methods Microbiol 19, 161-207.

Li, W. J., Xu, P., Schumann, P., Zhang, Y. Q., Pukall, R., Xu, L. H., Stackebrandt, E. \& Jiang, C. L. (2007). Georgenia ruanii sp. nov., a novel actinobacterium isolated from forest soil in Yunnan (China), and emended description of the genus Georgenia. Int J Syst Evol Microbiol 57, 1424-1428.

Marmur, J. (1961). A procedure for the isolation of deoxyribonucleic acid from microorganisms. J Mol Biol 3, 208-218.

Mata, J. A., Martínez-Cánovas, J., Quesada, E. \& Béjar, V. (2002). A detailed phenotypic characterisation of the type strains of Halomonas species. Syst Appl Microbiol 25, 360-375.

Mellado, E., Moore, E. R. B., Nieto, J. J. \& Ventosa, A. (1995). Phylogenetic inferences and taxonomic consequences of $16 \mathrm{~S}$ ribosomal DNA sequence comparison of Chromohalobacter marismortui, Volcaniella eurihalina, and Deleya salina and reclassification of $V$. eurihalina as Halomonas eurihalina comb. nov. Int J Syst Bacteriol 45, 712-716.

Mesbah, M., Premachandran, U. \& Whitman, W. B. (1989). Precise measurement of the $\mathrm{G}+\mathrm{C}$ content of deoxyribonucleic acid by highperformance liquid chromatography. Int J Syst Bacteriol 39, 159-167.

Minnikin, D. E., O'Donnell, A. G., Goodfellow, M., Alderson, G., Athalye, M., Schaal, A. \& Parlett, J. H. (1984). An integrated procedure for the extraction of bacterial isoprenoid quinones and polar lipids. J Microbiol Methods 2, 233-241.

Ntougias, S., Zervakis, G. I. \& Fasseas, C. (2007). Halotalea alkalilenta gen. nov., sp. nov., a novel osmotolerant and alkalitolerant bacterium from alkaline olive mill wastes, and emended description of the family Halomonadaceae Franzmann et al. 1989, emend. Dobson and Franzmann 1996. Int J Syst Evol Microbiol 57, 1975-1983.

Okamoto, T., Taguchi, H., Nakamura, K., Ikenaga, H., Kuraishi, H. \& Yamasato, K. (1993). Zymobacter palmae gen. nov., sp. nov., a new ethanol-fermenting peritrichous bacterium isolated from palm sap. Arch Microbiol 160, 333-337.

Okamoto, T., Kuraishi, H. \& Yamasato, K. (2005). Genus IV. Zymobacter Okamoto, Taguchi, Nakamura, Ikenaga, Kuraishi and Yamasato $1995,418^{\mathrm{VP}}$ (Effective publication: Okamoto, Taguchi, Nakamura, Ikenaga, Kuraishi and Yamasato 1993, 336). In Bergey's Manual of Systematic Bacteriology, 2nd edn, vol. 2, part B, pp. 319-
323. Edited by D. J. Brenner, N. R. Krieg, J. T. Staley \& G. M. Garrity. New York: Springer.

Peçonek, J., Gruber, C., Gallego, V., Ventosa, A., Busse, H. J., Kämpfer, P., Radax, C. \& Stan-Lotter, H. (2006). Reclassification of Pseudomonas beijerinckii Hof 1935 as Chromohalobacter beijerinckii comb. nov., and emended description of the species. Int J Syst Evol Microbiol 56, 1953-1957.

Reva, O. N., Vyunitskaya, V. A., Reznik, S. R., Kozachko, A. \& Smirnov, V. V. (1995). Antibiotic susceptibility as a taxonomic characteristic of the genus Bacillus. Int J Syst Bacteriol 45, 409-411.

Saitou, N. \& Nei, M. (1987). The neighbor-joining method: a new method for reconstructing phylogenetic trees. Mol Biol Evol 4, 406-425.

Sánchez-Porro, C., Tokunaga, H., Tokunaga, M. \& Ventosa, A. (2007). Chromohalobacter japonicus sp. nov., a moderately halophilic bacterium isolated from a Japanese salty food. Int J Syst Evol Microbiol 57, 2262-2266.

Sasser, M. (1990). Identification of bacteria by gas chromatography of cellular fatty acids. USFCC Newsl 20, 16.

Shirling, E. B. \& Gottlieb, D. (1966). Methods for characterization of Streptomyces species. Int J Syst Bacteriol 16, 313-340.

Smibert, R. M. \& Krieg, N. R. (1994). Phenotypic characterization. In Methods for General and Molecular Bacteriology, pp. 607-654. Edited by P. Gerhardt, R. G. E. Murray, W. A. Wood \& N. R. Krieg. Washington, DC: American Society for Microbiology.

Tamura, K., Dudley, J., Nei, M. \& Kumar, S. (2007). MEGA4: molecular evolutionary genetics analysis (MEGA) software version 4.0. Mol Biol Evol 24, 1596-1599.

Tang, S. K., Tian, X. P., Zhi, X. Y., Cai, M., Wu, J. Y., Yang, L. L., Xu, L. H. \& Li, W. J. (2008). Haloactinospora alba gen. nov., sp. nov., a halophilic filamentous actinomycete of the family Nocardiopsaceae. Int J Syst Evol Microbiol 58, 2075-2080.

Thompson, J. D., Gibson, T. J., Plewniak, F., Jeanmougin, F. \& Higgins, D. G. (1997). The CLUSTAL_X windows interface: flexible strategies for multiple sequence alignment aided by quality analysis tools. Nucleic Acids Res 25, 4876-4882.

Ventosa, A. (2005). Genus III. Chromohalobacter Ventosa, Gutierrez, García and Ruiz-Berraquero 1989, $384^{\mathrm{VP}}$ emend. Arahal, García, Ludwig, Schleifer and Ventosa 2001a, 1446. In Bergey's Manual of Systematic Bacteriology, 2nd edn, vol. 2, part B, pp. 316-319. Edited by D. J. Brenner, N. R. Krieg, J. T. Staley \& G. M. Garrity. New York: Springer.

Ventosa, A., Nieto, J. J. \& Oren, A. (1998). Biology of moderately halophilic aerobic bacteria. Microbiol Mol Biol Rev 62, 504-544.

Vreeland, R. H. (2005). Genus I. Halomonas Vreeland, Litchfield, Martin and Elliot 1980, 494 $\mathrm{VP}$ emend. Dobson and Franzmann 1996, 557. In Bergey's Manual of Systematic Bacteriology, 2nd edn, vol. 2, part B, pp. 300-313. Edited by D. J. Brenner, N. R. Krieg, J. T. Staley \& G. M. Garrity. New York: Springer.

Wayne, L. G., Brenner, D. J., Colwell, R. R., Grimont, P. A. D., Kandler, O., Krichevsky, M. I., Moore, L. H., Moore, W. E. C., Murray, R. G. E. \& other authors (1987). International Committee on Systematic Bacteriology. Report of the ad hoc committee on reconciliation of approaches to bacterial systematics. Int J Syst Bacteriol 37, 463-464.

Xu, P., Li, W. J., Tang, S. K., Zhang, Y. Q., Chen, G. Z., Chen, H. H., Xu, L. H. \& Jiang, C. L. (2005). Naxibacter alkalitolerans gen. nov., sp. nov., a novel member of the family 'Oxalobacteraceae' isolated from China. Int J Syst Evol Microbiol 55, 1149-1153.

Yoon, J. H., Lee, K. C., Kho, Y. H., Kang, K. H., Kim, C. J. \& Park, Y. H. (2002). Halomonas alimentaria sp. nov., isolated from jeotgal, a traditional Korean fermented seafood. Int J Syst Evol Microbiol 52, 123-130. 